\title{
Development of Human Breast Milk Microbiota-Associated Mice as a Method to Identify Breast Milk Bacteria Capable of Colonizing Gut
}

OPEN ACCESS

Edited by:

George Tsiamis,

University of Patras, Greece

Reviewed by:

Dimitris Tsaltas,

Cyprus University of Technology,

Cyprus

Yvette Marisa Piceno,

University of California,

San Francisco, United States

*Correspondence:

Jian Shen

shenjian@sjtu.edu.cn

Specialty section:

This article was submitted to

Systems Microbiology,

a section of the journal

Frontiers in Microbiology

Received: 19 April 2017 Accepted: 20 June 2017

Published: 11 July 2017

Citation:

Wang X, Lu H, Feng Z, Cao J, Fang $C, X U X$, Zhao $L$ and Shen J (2017) Development of Human Breast

Milk Microbiota-Associated Mice as a Method to Identify Breast Milk

Bacteria Capable of Colonizing Gut.

Front. Microbiol. 8:1242.

doi: 10.3389/fmicb.2017.01242

\section{Xiaoxin Wang ${ }^{1,2}$, Huifang $\mathrm{Lu}^{3}$, Zhou Feng ${ }^{2}$, Jie Cao ${ }^{1}$, Chao Fang ${ }^{1}$, Xianming Xu ${ }^{3}$, Liping Zhao ${ }^{1,2}$ and Jian Shen ${ }^{1 *}$}

${ }^{1}$ Key Laboratory of Systems Biomedicine (Ministry of Education), Shanghai Center for Systems Biomedicine, Shanghai Jiao Tong University, Shanghai, China, ${ }^{2}$ State Key Laboratory of Microbial Metabolism, School of Life Sciences and Biotechnology, Shanghai Jiao Tong University, Shanghai, China, ${ }^{3}$ Shanghai General Hospital, Shanghai, China

Human breast milk is recognized as one of multiple important sources of commensal bacteria for infant gut. Previous studies searched for the bacterial strains shared between breast milk and infant feces by isolating bacteria and performing strainlevel bacterial genotyping, but only limited number of milk bacteria were identified to colonize infant gut, including bacteria from Bifidobacterium, Staphylococcus, Lactobacillus, and Escherichia/Shigella. Here, to identify the breast milk bacteria capable of colonizing gut without the interference of bacteria of origins other than the milk or the necessity to analyze infant feces, normal chow-fed germ-free mice were orally inoculated with the breast milk collected from a mother 2 days after vaginal delivery. According to $16 \mathrm{~S}$ rRNA gene-based denaturant gradient gel electrophoresis and Illumina sequencing, bacteria at $>1 \%$ abundance in the milk inoculum were only Streptococcus (56.0\%) and Staphylococcus (37.4\%), but in the feces of recipient mice were Streptococcus (80.3 $\pm 2.3 \%)$, Corynebacterium (10.0 $\pm 2.6 \%)$, Staphylococcus (7.6 $\pm 1.6 \%)$, and Propionibacterium $(2.1 \pm 0.5 \%)$ that were previously shown as dominant bacterial genera in the meconium of $\mathrm{C}$-section-delivered human babies; the abundance of anaerobic gut-associated bacteria, Faecalibacterium, Prevotella, Roseburia, Ruminococcus, and Bacteroides, was $0.01-1 \%$ in the milk inoculum and 0.003-0.01\% in mouse feces; the abundance of Bifidobacterium spp. was below the detection limit of Illumina sequencing in the milk but at $0.003-0.01 \%$ in mouse feces. The human breast milk microbiota-associated mouse model may be used to identify additional breast milk bacteria that potentially colonize infant gut.

Keywords: breast milk, germfree mice, gut, bacteria, gnotobiotic

\section{INTRODUCTION}

Although human breast milk-associated microbiota is dominated by skin-associated bacteria Staphylococcus and Streptococcus (Jost et al., 2013; Charbonneau et al., 2016), breast milk is considered an important source of commensal bacteria for the neonatal gut, because DNA of gut-associated bacteria, including Bacteroides, Clostridium, Faecalibacterium, Roseburia, and 
Bifidobacterium, etc., have been repeatedly detected at low abundance in milk in different studies using 16S rRNA gene-based molecular approaches (Gueimonde et al., 2007; Martin R. et al., 2007; Perez et al., 2007; Collado et al., 2009; Hunt et al., 2011; Cabrera-Rubio et al., 2012; Jost et al., 2013, 2014). To investigate what breast milk bacteria can colonize infant gut, i.e., the mother-neonate vertical transfer of bacteria via breastfeeding, numerous studies searched for the bacterial species/strains shared between breast milk and infant feces in mother-infant pairs by microbiologically isolating bacteria and strain-level genotyping of the bacterial isolates (Martin et al., 2006, 2012; Jost et al., 2014). From thousands of bacterial isolates of the maternal breast milk and infant feces, only a limited number of bacterial species (Bifidobacterium breve, B. longum, Staphylococcus epidermidis, S. hominis, Lactobacillus fermentum, L. gasseri, L. plantarum, L. reuteri, L. salivarius, L. vaginalis, and Escherichia/Shigella spp.) were found to be shared by a few mother-infant pairs (Martin et al., 2006, 2012; Jost et al., 2014). This is probably because the human neonatal gut microbiota receives bacteria from multiple sources other than breast milk, including mothers' feces, vaginal tract, skin and the surrounding environment during delivery. Therefore, alternative methods are needed to identify additional candidate bacteria that are potentially transferred from the mothers' breast milk to infant gut.

Germ-free mice provide an animal model in which the source of commensal bacteria can be strictly controlled and microbiological contamination from other origins is avoided. They have been shown to be an effective surrogate host of human gut bacteria (Kibe et al., 2005; Turnbaugh et al., 2009; Ridaura et al., 2013). Over $85 \%$ of the bacterial genera present in the adult human donors' feces, including Bacteroides, Faecalibacterium, and Roseburia, etc., can be detected in recipient ex-germ-free mice that were gavaged with human fecal suspension (Turnbaugh et al., 2009). A human baby microbiota, which consisted of bacteria of Bacteroides, Enterobacteria, Bifidobacterium, Lactobacillus, and Staphylococcus isolated from the feces a 20-day-old female baby, can stably colonize the gut of germfree mice (Martin et al., 2007). No previous study has transplanted human breast milk microbiota to germfree mice to screen for the breast milk bacteria that can colonize the gut.

In the present study, germ-free mice fed on normal chow were inoculated orally with the breast milk of one 38-year-old mother 2 days after vaginal delivery, and the microbiota composition of milk inoculum and mouse feces were compared with 16S rRNA gene profiling and microbiological culture techniques.

\section{MATERIALS AND METHODS}

\section{Subject and Breast Milk Collection}

The breast milk was collected from a 38-year-old mother 2 days after vaginal delivery at term. The mother had gestational diabetes mellitus during pregnancy (the serum glucose levels of Oral Glucose Tolerance Test were fasting $4.23 \mathrm{mmol} / \mathrm{L}$, $1 \mathrm{~h} 10.6 \mathrm{mmol} / \mathrm{L}$, and $2 \mathrm{~h} 10.28 \mathrm{mmol} / \mathrm{L})$. She had no gastrointestinal diseases, immunological disorders, infectious diseases, or organic diseases. The mother received no antibiotics within 3 months before breast milk sampling, and she performed exclusive breastfeeding when the milk sample was collected. The protocol of the study was approved by the Ethical Committee of Shanghai General Hospital. Written informed consent was obtained from the mother before the participation in the study.

The breast was first washed with sterile water, subsequently, the nipple and areola were swabbed with An'erdian ${ }^{\circledR}$ type III skin antiseptic solution containing $0.5 \%(\mathrm{w} / \mathrm{v})$ available iodine and $0.1 \%(\mathrm{w} / \mathrm{v})$ chlorhexidine gluconate (LiKang, Shanghai, China) and then swabbed with sterile water. Wearing single-use sterile rubber surgical gloves, the nurse manually collected the breast milk into a sterile tube after discarding the first drops $(\sim 100 \mu \mathrm{l})$.

The breast milk was immediately transported to the lab in an anaerobic jar. Aliquots of the breast milk were inoculated to germ-free mice, and processed for bacterial cultivation in an anaerobic chamber within $2 \mathrm{~h}$ after collection. Further aliquots were stored at $-80^{\circ} \mathrm{C}$ for DNA extraction.

\section{Animal Experiments}

All experimental procedures and protocols were approved by the Institutional Animal Care and Use Committee of Laboratory Animals of Shanghai Laboratory Animal Center (SLAC), Chinese Academy of Sciences, Shanghai, China.

Ten weaned germfree male C57BL/6J mice were raised in a Trexler-type flexible-film plastic isolator with a regular $12 \mathrm{~h}$ light cycle (lights on at $0600 \mathrm{~h}$ ) in SLAC. They were provided with sterile normal chow (containing $4.62 \%$ fat, $3.45 \mathrm{kcal} \mathrm{g}^{-1}$, from SLAC Inc., Shanghai, China) and water ad libitum. Periodic bacteriologic examination of feces with bacterial cultivation was performed to make sure there was no bacterial contamination.

At the age of 8 weeks, each of the 10 mice was inoculated with $100 \mu \mathrm{l}$ freshly collected breast milk by gavage, and a repeat inoculation of the identical milk sample was conducted on the third day. The experiment lasted 8 weeks since the first inoculation. Fresh stool samples were collected from each mouse weekly and frozen at $-80^{\circ} \mathrm{C}$ for DNA extraction. At week 8 , one aliquot of the feces collected from No. 4 recipient mouse was used for bacterial isolation.

\section{DNA Extraction from the Breast Milk and Mouse Feces}

Two milliliters of breast milk was centrifuged at 9,000 $\times g$ for $20 \mathrm{~min}$ to collect the bacterial cell pellets. For the feces of mice, one fecal pellet was homogenized in $0.5 \mathrm{ml}$ phosphate buffered saline supplemented with $0.05 \%(\mathrm{w} / \mathrm{v})$ L-cysteine and centrifuged as above. Total DNA was extracted from the resultant bacterial cell pellets as previously described (Godon et al., 1997) and as specified in Supplementary Information, and purified with Omega Gel Extraction kit (D2501-01, OMEGA Bio-Tek, Taiwan, China). The integrity of the DNA was assessed by using $0.8 \%$ agarose gel electrophoresis gels stained with ethidium bromide, and the concentration was quantified with PicoGreen fluorescent dye (Thermo Fisher Scientific, Sunnyvale, CA, United States) by 
using SpectraMax M5 microplate reader (Molecular Devices, San Francisco, CA, United States).

\section{DGGE of 16S rRNA Gene V3 Region Amplicons}

The 16S rRNA gene V3 region was PCR amplified with the genomic DNA extracted from the breast milk and feces of recipient mice as the template. The primer p2 $\left(5^{\prime}-\mathrm{ATT}\right.$ ACCGCGGCTGCTGG-3') and p3 (5'-CGCCCGCCGCGCGCG GCGGGCGGGGCGGGGGCACGGGGGGCCTACGGGAGGC AGCAG-3') (Muyzer et al., 1993) were used. The $25 \mu l$ PCR mixture contained $10 \mathrm{ng}$ of DNA templates, $0.75 \mathrm{U}$ of TaKaRa rTaq polymerase (Takara, Dalian, China), $1 \times$ PCR buffer $\left(\mathrm{Mg}^{2+}\right.$ free), $2 \mathrm{mM} \mathrm{MgCl}_{2}, 6.25 \mathrm{pmol}$ of each of the primer, each deoxynucleoside triphosphate at a concentration of $200 \mu \mathrm{M}$. The PCR program included the following steps: an initial denaturation at $94^{\circ} \mathrm{C}$ for $3 \mathrm{~min} ; 20$ cycles of touchdown PCR consisting of denaturation at $94^{\circ} \mathrm{C}$ for $1 \mathrm{~min}$, annealing for $1 \mathrm{~min}$ at temperatures decreasing from 65 to $55^{\circ} \mathrm{C}$ with $1^{\circ} \mathrm{C}$ interval every second cycle, and extension at $72^{\circ} \mathrm{C}$ for $1 \mathrm{~min} ; 5$ cycles of regular PCR $\left(94^{\circ} \mathrm{C}\right.$ for $1 \mathrm{~min}, 55^{\circ} \mathrm{C}$ for $1 \mathrm{~min}$, and $72^{\circ} \mathrm{C}$ for $1 \mathrm{~min}$ ); a final extension step for $6 \mathrm{~min}$ at $72^{\circ} \mathrm{C}$. The sizes of PCR products were assessed using $1.5 \%$ agarose gel electrophoresis gels stained with ethidium bromide.

DGGE was performed with the Dcode System apparatus (Bio-Rad, Hercules, CA, United States). PCR products (300 ng) were separated on $8 \%(\mathrm{w} / \mathrm{v})$ polyacrylamide gels with a denaturing gradient of $27-55 \%$. The $100 \%$ denaturant corresponds to $7 \mathrm{M}$ urea and $40 \%$ deionized formamide. Electrophoresis was performed in $1 \times$ Tris-acetate-EDTA (TAE) buffer at a constant voltage of $200 \mathrm{~V}$ and a temperature of $60^{\circ} \mathrm{C}$ for $4 \mathrm{~h}$. Gels were stained with SYBR green I (Amresco, Solon, $\mathrm{OH}$, United States) and were photographed with a UVI gel documentation system (Tanon-3500, Beijing, China).

Quantity One software (version 4.4.0, Bio-Rad, Hercules, CA, United States) was used to digitize the DGGE profiles by determining the migration position and intensity of DGGE bands. Bands migrating to an identical position were considered to represent the same bacterial species. Dendrogram of the DGGE profiles was generated based on the similarity of profiles with UPGAMA clustering analysis using the Quantity One software.

\section{DNA Sequencing of DGGE Bands}

The DGGE bands were excised from the gels with a sterile knife and incubated in $100 \mu \mathrm{l}$ sterile distilled water at $4^{\circ} \mathrm{C}$ overnight. The $16 \mathrm{~S}$ rRNA gene $\mathrm{V} 3$ region in the band was re-amplified using $4 \mu \mathrm{l}$ eluate as the template and the primer pair $\mathrm{p} 2$ and $\mathrm{p} 3$. PCR products were purified using the Gel Extraction Kit (Omega, United States), ligated into the pGEM-T easy vector (Promega, Madison, WI, United States), and transformed into competent Escherichia coli DH5a cells. Positive clones were picked randomly, and inserts were amplified and screened for their migration position by DGGE. Clones that migrated to the same position as the original DGGE bands were sequenced (Life Technologies, Shanghai, China).

\section{Illumina Sequencing of Bacteria 16S rRNA Gene V3-V4 Regions}

For the breast milk and feces of recipient mice, the sequencing library of $16 \mathrm{~S}$ rRNA gene V3-V4 regions was prepared with two steps of amplification according to the protocol provided by Illumina ${ }^{1}$ with the following modifications. For the Amplicon PCR (amplification of 16S rRNA gene V3-V4 region), the $25 \mu \mathrm{l}$ reaction mix consisted of $1.6 \times$ Pfx amplification buffer, $1 \mathrm{mM}$ $\mathrm{MgSO}_{4}, 0.3 \mathrm{mM}$ dNTP, $0.2 \mu \mathrm{M}$ of each specific primer for V3-V4 region of $16 \mathrm{~S}$ rRNA gene as described in the Illumina protocol, 0.75 U of Platinum Pfx DNA polymerase (C11708021, Invitrogen, United States), and 12 ng template DNA. The PCR cycle number was reduced to 21 to diminish bias. The program was started with pre-denaturation at $95^{\circ} \mathrm{C}$ for $3 \mathrm{~min}$, followed by 22 cycles of denaturation at $94^{\circ} \mathrm{C}$ for $30 \mathrm{~s}$, annealing at $55^{\circ} \mathrm{C}$ for $30 \mathrm{~s}$ and extension at $72^{\circ} \mathrm{C}$ for $30 \mathrm{~s}$, and ended up with a final extension at $72^{\circ} \mathrm{C}$ for $5 \mathrm{~min}$. For the Index PCR (attachment of dual indices and Illumina sequencing adapter using the Nextera XT Index Kit), the $25 \mu \mathrm{l}$ reaction mix consisted of $1.0 \times \mathrm{Pfx}$ amplification buffer, $1 \mathrm{mM} \mathrm{MgSO} 4,0.2 \mathrm{mM}$ dNTP, $2.5 \mu \mathrm{l}$ of each N7 and S5 Index primers as described in the protocol, $0.5 \mathrm{U}$ of Platinum Pfx DNA polymerase, and $2.5 \mu \mathrm{l}$ purified products of the Amplicon PCR step as template DNA. The PCR program of Index PCR was the same as Amplicon PCR except that the cycle number was reduced to 8 . The purified products of the Index PCR were mixed at equal ratio and sequenced using the Illumina MiSeq System (Illumina Inc., United States).

\section{Bacterial Isolation and DNA Extraction}

Bacteria were isolated from the breast milk inoculum and the feces of No. 4 recipient mouse at week 8. Wilkins-Chalgren Agar [WCH] (Hopebiol, Qingdao, China) as a non-selective medium for anaerobic bacteria (Jimenez et al., 2008; Jost et al., 2013) and M17 medium (Hopebiol, Qingdao, China) for streptococci, lactococci, and enterococci (Heikkila and Saris, 2003) were used for bacterial isolation. Three aliquots of $100 \mu \mathrm{l}$ fresh milk or homogenized fecal suspension serially diluted by 10 -fold were plated in triplicate on each agar medium. The plates were incubated in an anaerobic workstation (DG500, DWS, United Kingdom) at $37^{\circ} \mathrm{C}$ for $48 \mathrm{~h}$. The bacterial population levels were reported as $\log$ colony-forming units $(\mathrm{cfu}) / \mathrm{ml}$ breast milk or log $\mathrm{cfu} / \mathrm{g}$ feces.

Based on different morphologies, colonies were randomly selected per sample and agar medium, streaked three times for purity and cultured in liquid Anaerobe Basal Broth medium [ABB] (Nissui, Qingdao, China). Aliquots of the suspension of viable isolates were stored at $-80^{\circ} \mathrm{C}$ in liquid $\mathrm{ABB}$ medium supplemented with $30 \%(\mathrm{v} / \mathrm{v})$ glycerol and covered by $300 \mu \mathrm{l}$ paraffin oil.

To extract the genomic DNA from each viable bacterial isolate, $3 \mathrm{ml}$ suspension of the isolate after $48 \mathrm{~h}$ cultivation was centrifuged at $9000 \times g$ for $5 \mathrm{~min}$. The bacterial cell pellets were re-suspended in $475 \mu \mathrm{l}$ TE buffer $(10 \mathrm{mM}$ Tris- $\mathrm{HCl}, 1 \mathrm{mM}$

\footnotetext{
${ }^{1}$ http://support.illumina.com.cn/content/dam/illumina-

support/documents/documentation/chemistry_documentation/16s/16smetagenomic-library-prep-guide-15044223-b.pdf
} 
EDTA, pH 8.0). Twenty-five microliter lysozyme $(50 \mathrm{mg} / \mathrm{ml})$ was added and the mixture was incubated at $37^{\circ} \mathrm{C}$ for $1 \mathrm{~h}$. Then, $5 \mu \mathrm{l}$ of Proteinase $\mathrm{K}(20 \mathrm{mg} / \mathrm{ml})$ and $50 \mu \mathrm{l}$ of $20 \%$ SDS were added and the mixture was incubated at $55^{\circ} \mathrm{C}$ for $30 \mathrm{~min}$. The suspension was sequentially extracted by equal volumes of phenol, phenol/chloroform/isoamyl alcohol (vol/vol/vol 25:24:1), and chloroform/isoamyl alcohol (vol/vol, 24:1). DNA was precipitated with two volumes of ethanol at $-20^{\circ} \mathrm{C}$ for $2 \mathrm{~h}$, collected by centrifugation at $14,000 \mathrm{rpm}$ for $15 \mathrm{~min}$, washed twice with $500 \mu \mathrm{l}$ ice-cold $70 \%$ (v/v) ethanol and air dried. DNA was re-suspended in $50 \mu \mathrm{l}$ TE buffer. RNA was digested by adding $20 \mu \mathrm{l}$ RNase $(20 \mathrm{mg} / \mathrm{ml})$ and incubating at $37^{\circ} \mathrm{C}$ for $30 \mathrm{~min}$. The amount of DNA was determined with PicoGreen fluorescent dye (Thermo Fisher Scientific, Sunnyvale, CA, United States) by using SpectraMax M5 microplate reader (Molecular Devices, San Francisco, CA, United States), and its integrity was checked by $0.8 \%$ agarose gel electrophoresis stained by ethidium bromide.

\section{Enterobacterial Repetitive Intergenic Consensus Sequence-PCR}

The bacterial isolates were genotyped by ERIC-PCR with the primer pair ERIC1 (5'-ATGTAAGCTCCTGGGGATTCAC-3') and ERIC2 (5'-AAGTAAGTGACTGGGGTGAGCG-3')

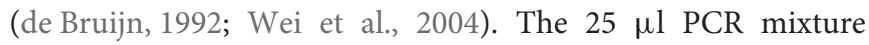
contained $20 \mathrm{ng}$ of bacterial genomic DNA, $200 \mathrm{mM}$ each dNTP, $2.5 \mathrm{U}$ of TaKaRa rTaq polymerase (Takara, Dalian, China), $1 \times$ reaction buffer, $2 \mathrm{mM} \mathrm{MgCl}_{2}$, and $10 \mathrm{pM}$ of each primer. The amplification program was as follows: pre-denaturation at $95^{\circ} \mathrm{C}$ for $7 \mathrm{~min}, 30$ cycles of denaturation at $95^{\circ} \mathrm{C}$ for $30 \mathrm{~s}$, annealing at $52^{\circ} \mathrm{C}$ for $1 \mathrm{~min}$, and extension at $65^{\circ} \mathrm{C}$ for $8 \mathrm{~min}$, and a final extension at $65^{\circ} \mathrm{C}$ for $16 \mathrm{~min}$. $400 \mathrm{ng}$ of PCR products were separated by electrophoresis on a $1.5 \%$ (wt/vol) agarose gel.

\section{Full-Length 16S rRNA Genes Sequencing of Representative Bacterial Isolates}

One representative isolate of each ERIC type was subjected to full-length $16 \mathrm{~S}$ rRNA gene sequencing. Universal bacterial primers 27f ( $5^{\prime}$-AGAGTTTGATCCTGGCTCAG-3') and 1492r (5'-CGGC/TTACCTTGTTACGACTT-3') were used. The $25 \mu \mathrm{l}$ mixture contained $0.75 \mathrm{U}$ of rTaq polymerase (Takara, Dalian, China), $1 \times$ PCR buffer $\left(\mathrm{Mg}^{2+}\right.$ free $), 2 \mathrm{mM} \mathrm{MgCl}_{2}, 10 \mathrm{pmol}$ of each primer, $200 \mu \mathrm{M}$ each $\mathrm{dNTP}$, and $10 \mathrm{ng}$ of bacterial genomic DNA as the template. A 25 cycles PCR program was performed as follows: pre-denaturation at $95^{\circ} \mathrm{C}$ for $7 \mathrm{~min}, 30$ cycles of denaturation at $94^{\circ} \mathrm{C}$ for $30 \mathrm{~s}$, annealing at $52^{\circ} \mathrm{C}$ for $1 \mathrm{~min}$, and extension at $65^{\circ} \mathrm{C}$ for $8 \mathrm{~min}$, and a final extension at $65^{\circ} \mathrm{C}$ for $16 \mathrm{~min}$.

PCR products were purified using the Gel Extraction Kit 200 (Omega, United States), ligated into the pGEM-T easy vector (Promega, Madison, WI, United States), and transformed into competent E. coli DH5a cells. Positive clones were picked randomly, amplified with T7 and SP6 as the primers. For each isolate, three positive clones were sequenced (Life Technologies, Shanghai, China).

\section{Bioinformatics Analysis}

The 16S rRNA gene sequences obtained from the DGGE bands and bacterial isolates were blasted against the $\mathrm{nr}$ database of Genbank using the basic local alignment search tool (BLAST) ${ }^{2}$, and their closest relative bacteria were determined. A neighborjoining phylogenetic tree containing the sequences and their relatives was constructed with the Molecular Evolutionary Genetics Analysis package (MEGA5) with the Jukes-Cantor algorithm. The phylogenetic robustness was assessed by bootstrap analysis with 1000 replicates using the same software. The taxonomy of the bacterial isolates and bacteria represented by the DGGE bands was determined based on the position of their sequences in the phylogenetic tree.

For the raw data of Illumina sequencing of $16 \mathrm{~S}$ rRNA gene V3-V4 amplicons, both the forward and reverse ends of the same read were truncated at the first base where the $\mathrm{Q}$ value became no more than 2. Using USEARCH v8.0.1623, individual pairs of reads were merged into a complete read only if they had a minimum overlap of $50 \mathrm{bp}$. The merged reads that were longer than 399 nt with an expected error of no more than 0.5 were kept for further processing. Quality-filtered reads were delineated into unique sequences and then sorted by decreasing abundance, and singletons were discarded. OTUs were clustered de novo with Uparse (Edgar, 2013) at 97\% similarity level. Reference-based chimera detection was performed using UCHIME (Edgar et al., 2011) against the RDP classifier training database (v9) (Cole et al., 2014). The OTU table was finalized by mapping quality-filtered reads to the remaining OTUs with the Usearch (Edgar, 2010) global alignment algorithm at a $97 \%$ cutoff. Sequence data were rarefied to 25,000 reads per sample (1,000 permutations) to avoid bias caused by the difference in sequencing depth. Representative sequences for each OTU were subjected to the RDP classifier to determine the taxonomy with a bootstrap cutoff of $80 \%$ (RDP database version 2.10).

\section{Accession Number}

The full-length 16S rRNA gene sequences of the representative bacterial strains isolated from the breast milk and mouse feces and the 16S rRNA gene V3 region sequences of the DGGE band sequences were deposited in GenBank under accession numbers KY038179-KY038195 and KY082697-KY082707, respectively.

$16 \mathrm{~S}$ rRNA gene V3-V4 region Illumina sequences of the breast milk and mice feces were deposited in NCBI Sequence Read Archive (SRA) under accession numbers PRJNA351774 (breast milk), PRJNA351775 (mice at week 8), and PRJNA377923 (mice at weeks 1-6).

\section{RESULTS}

\section{The Colonization of Breast Milk Bacteria in Germ-Free Mice Monitored by DGGE}

DGGE of $16 \mathrm{~S}$ rRNA gene V3 region amplicons detects bacteria representing more than $1 \%$ of the whole community (Muyzer

\footnotetext{
${ }^{2}$ https://blast.ncbi.nlm.nih.gov/Blast.cgi?PROGRAM=blastn\&PAGE_TYPE= BlastSearch\&LINK_LOC=blasthome
} 
A
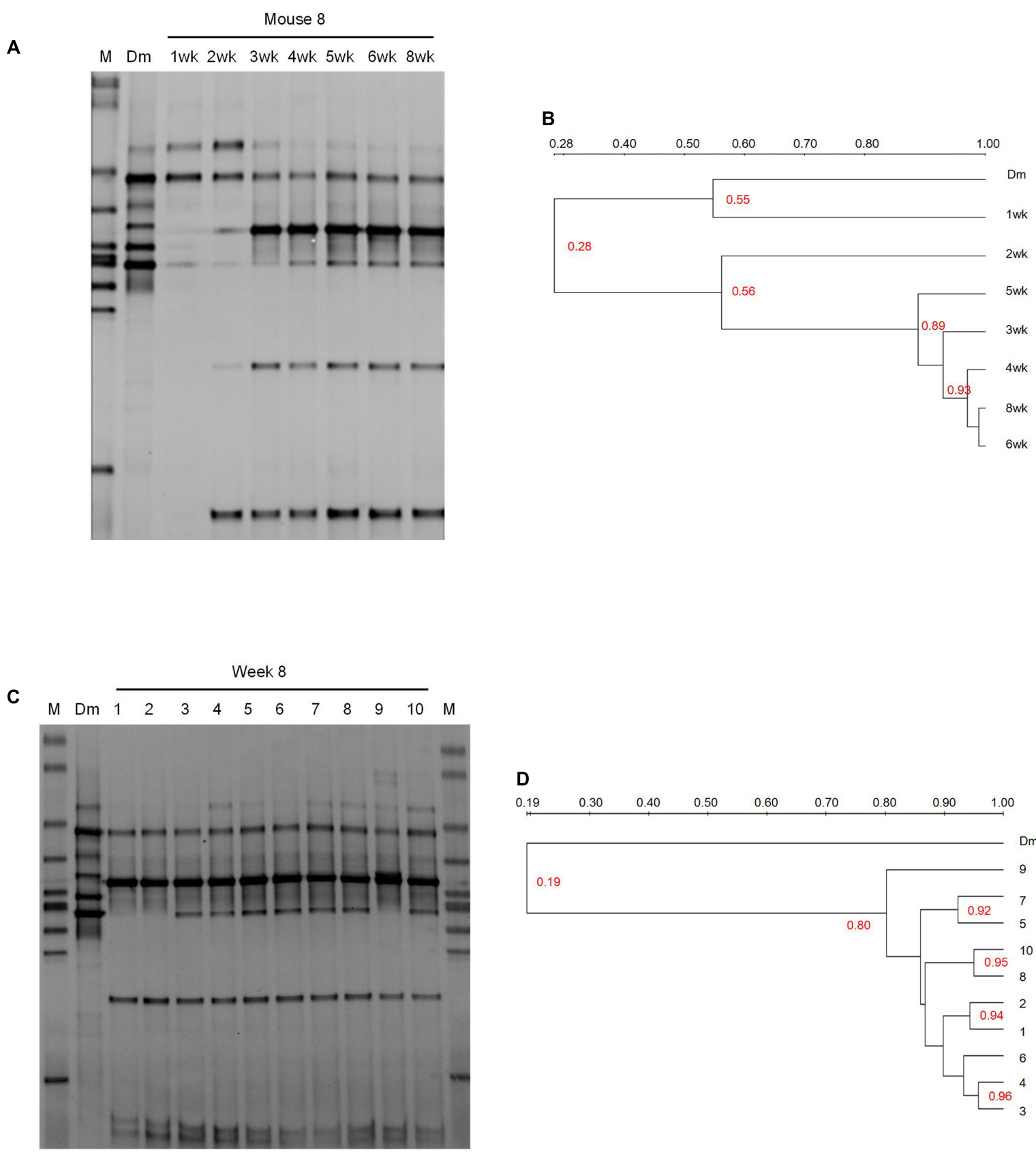

\section{D}
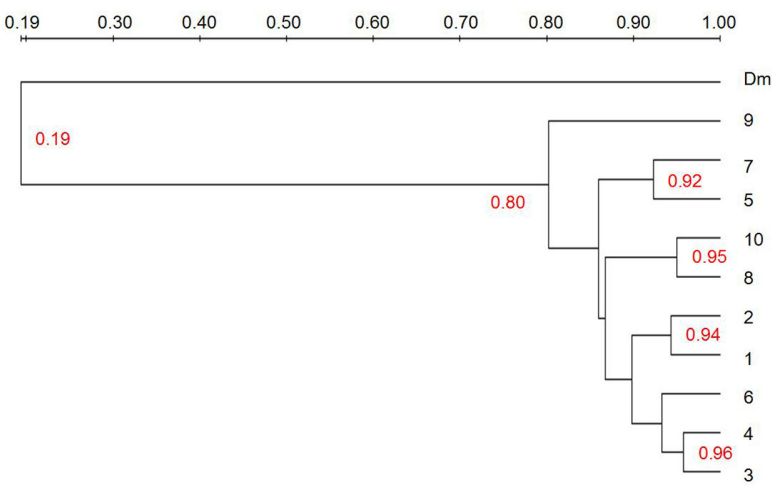

FIGURE 1 | DGGE profiling of the bacterial communities in the breast milk inoculum and feces of recipient mice. (A) The weekly monitor of the gut microbiota composition of one recipient mouse (No. 8 mouse) after the inoculation of breast milk. (B) Dendrogram of the DGGE profiles shown in (A). (C) The comparison of the bacterial composition between the breast milk inoculum and the feces of recipient mice at 8 weeks. (D) Dendrogram of the DGGE profiles shown in (C). Dendrogram of the DGGE profiles was generated based on the similarity of profiles with UPGAMA clustering analysis using the Quantity One software. M, DGGE marker. Dm, breast milk. wk, week.

et al., 1993). We here performed DGGE and clustering analysis of the DGGE profiles to compare bacterial composition of the milk inoculum and the feces of recipient mice (Figure 1 and Supplementary Figure S1).

The fecal microbiota of recipient mice became stabilized by 2-4 weeks after gavage according to clustering dendrogram of DGGE profiles of mice at different time points (Figures 1A,B and
Supplementary Figure S1). At 8 weeks, the DGGE profiles of all 10 recipient mice clustered together with the similarity between 80 and $96 \%$, but clustered separately from that of the breast milk with the similarity as low as $19 \%$ (Figures 1C,D). This suggests that despite the small inter-individual variation, the composition of gut microbiota of different recipient mice was similar but was significantly different from that of the breast milk inoculum. 


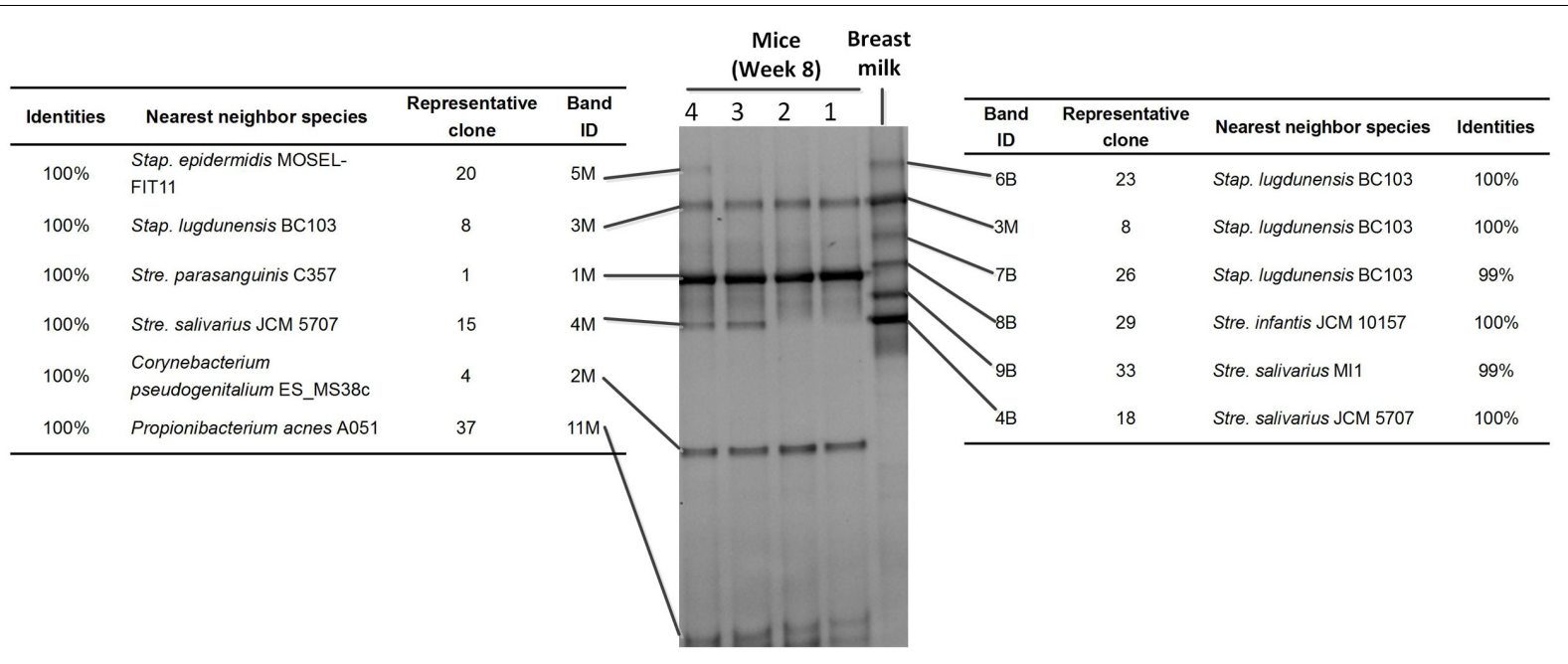

FIGURE 2 | Sequence analysis of dominant bands in the 16S rRNA gene V3 region DGGE profiles of Mouse feces and Breast milk. The 16S rRNA gene V3 region DNA in each DGGE band was excised, re-amplified, cloned, and sequences. Indicated are the band ID, the representative clones, the bacterial species most closely related to the clones, and the levels of similarity.

The DGGE bands were excised, cloned, and sequenced (Figure 2). There were six bands in the profile of the breast milk; and among them, three were from Staphylococcus lugdunensis-like species, one from a Streptococcus infantislike species, and two from Streptococcus salivarius-like species (Figure 2).

Only two breast milk bands (band $3 \mathrm{M}$ and $4 \mathrm{M}$ ), from a S. lugdunensis-like species and a Str. salivarius-like species, respectively, were still present in the feces of the recipient mice. Four bands (5M, 1M, 2M, and 11M), representing S. epidermidis, Str. parasanguinis, Corynebacterium pseudogenitalium, and Propionibacterium acnes-like species, respectively, were not detectable in the breast milk, but appeared in mice (Figure 2). Band 4M and 5M (from a Str. salivarius-like and a S. epidermidislike species, respectively) were detected in seven mice, and band $3 \mathrm{M}, 1 \mathrm{M}, 2 \mathrm{M}$, and $11 \mathrm{M}$ (from a S. lugdunensis-like, Str. parasanguinis, C. pseudogenitalium, and P. acnes-like species, respectively) were detected in all 10 mice (Figure 1). The above six DGGE bands represented the breast milk bacteria that stably colonized the gut of recipient mice at the abundance $>1 \%$.

\section{The Colonization of Breast Milk Bacteria in Germ-Free Mice Monitored with Illumina Sequencing of 16S rRNA Gene V3-V4 Region}

The breast milk inoculum and feces of 10 recipient mice at weeks $1,2,3,4,5,6$, and 8 were subjected to Illumina sequencing of 16S rRNA gene V3-V4 regions, and 25366 and $46303 \pm 26452$ (median 34864, upper quartile 51414, and lower quartile 30531) high-quality reads were obtained for the milk and the mouse feces, respectively. The sequences were binned into OTUs at the 97\% similarity level, and 165 OTUs were generated after chimeras and singleton filtering.
Thirty-seven OTUs were present in both the milk and Week 8 mouse feces (Table 1 and Supplementary Table S1), 51 were detected only in the milk (Table 2 and Supplementary Table S1), and 19 existed only in the mouse feces (Table 3 and Supplementary Table S1).

Three OTUs from Staphylococcus (OTU2) and Streptococcus (OTU1 and OTU4), were among the most abundant bacteria in both the milk and feces of 10 mice at week 8; the abundance of Staphylococcus decreased from $37.4 \%$ in the milk to $7.6 \pm 1.6 \%$ (range $5.6-11.1 \%$ ) in the feces of recipient mice, in contrast, the abundance of Streptococcus (OTU1 and OTU4) increased from $56.0 \%$ in the milk to $80.3 \pm 2.3 \%$ (range 77.6-86.3\%) in the mouse feces (Table 1). Two OTUs, from Corynebacterium (OTU3) and Propionibacterium (OTU5), respectively, accounted for only 0.004 and $0.02 \%$ in the breast milk, but became much more abundant in 10 mice at week 8 with the abundance $10.0 \pm 2.6 \%$ (range 5.8-14.3\%) and $2.1 \pm 0.5 \%$ (range 1.0-2.7\%), respectively (Table 1). In the gut of recipient mice at week 8 , only the above five OTUs were at abundance $>1 \%$, and the abundance of Streptococcus (range 77.6-86.3\%), Corynebacterium (range 5.8-14.3\%), Staphylococcus (range 5.6-11.1\%), and Propionibacterium (range 1-2.7\%) generally decreased sequentially (Table 1 ). The above 5 OTUs were detected in all 10 mice at most of the time points $(>5)$ from weeks 1 to 8 , and their abundances remained stable from weeks 6 to 8 (Supplementary Figure S2 and Table S2).

Some gut-associated anaerobic bacteria from Faecalibacterium (OTU6), Prevotella (OTU11), Roseburia (OTU8), Unclassified Lachnospiraceae (OTU39), Ruminococcus (OTU27), and Bacteroides (OTU13) were present at low abundance in the milk inoculum (0.01-1\%) and in the feces of some but not all recipient mice at week $8(0.003-0.01 \%)$ (Table 1). These bacteria were detected at multiple time points from weeks 1 to 8 in mice harboring them. Faecalibacterium (OTU6) was detected at 3-5 time points in four mice, Prevotella (OTU11) 
TABLE 1 | OTUs detected in both the breast milk inoculum and feces of recipient mice at week 8.

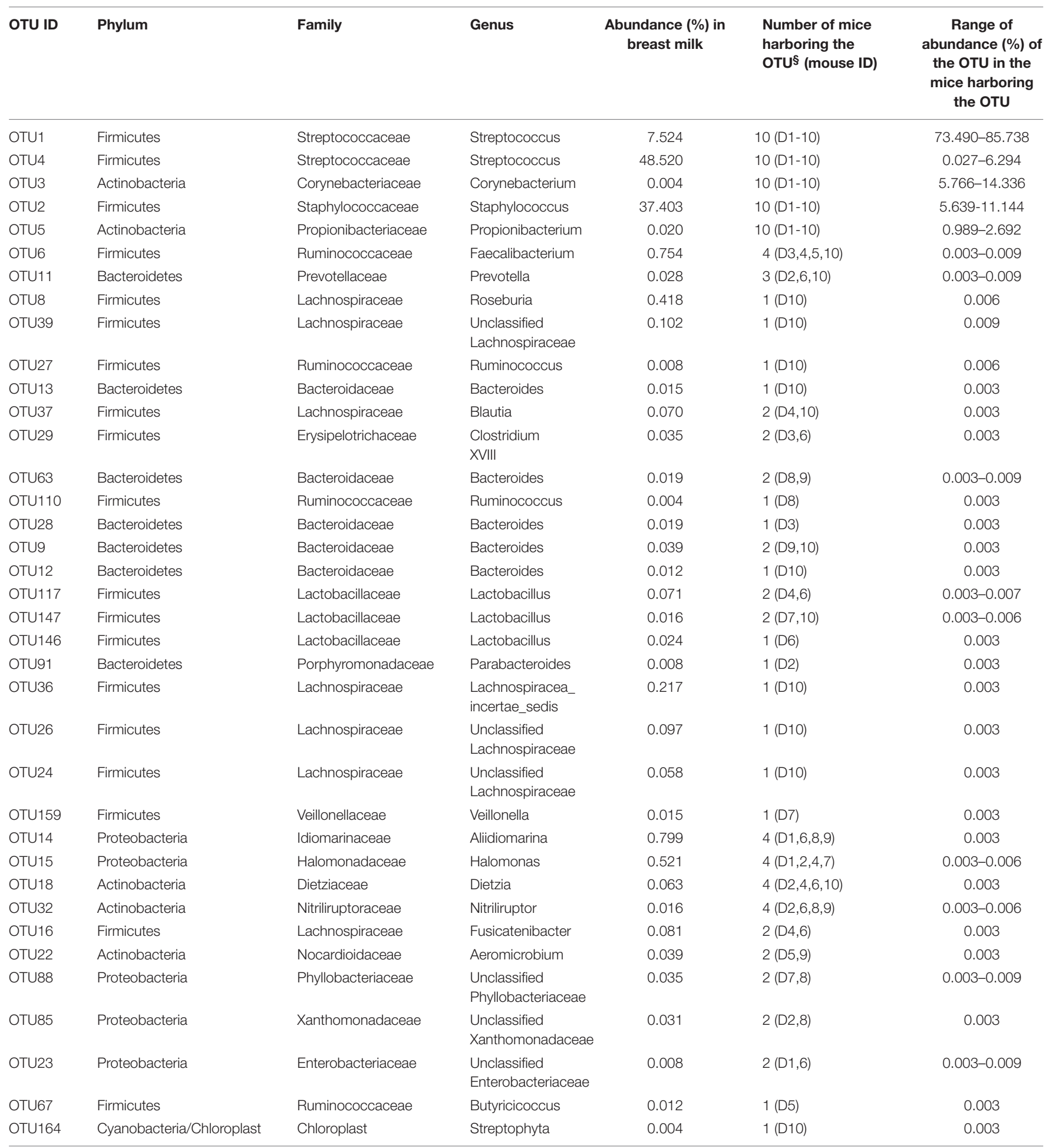

§Ten mice in total.

was detected at $4-5$ time points in three mice, and Roseburia (OTU8), Unclassified Lachnospiraceae (OTU39), Ruminococcus (OTU27), and Bacteroides (OTU13) were present in one mouse at 2-3 time points (Supplementary Figure S3 and Table S2).
Moreover, their abundances stayed at $0.003-0.01 \%$ from weeks 6 to 8 (Supplementary Figure S3 and Table S2).

Some bacteria, such as Gemella (OTU74), Dialister (OTU113), Dorea (OTU49), were detected only in the breast milk 
TABLE 2 | OTUs detected in the breast milk inoculum but not in the feces of recipient mice at week 8.

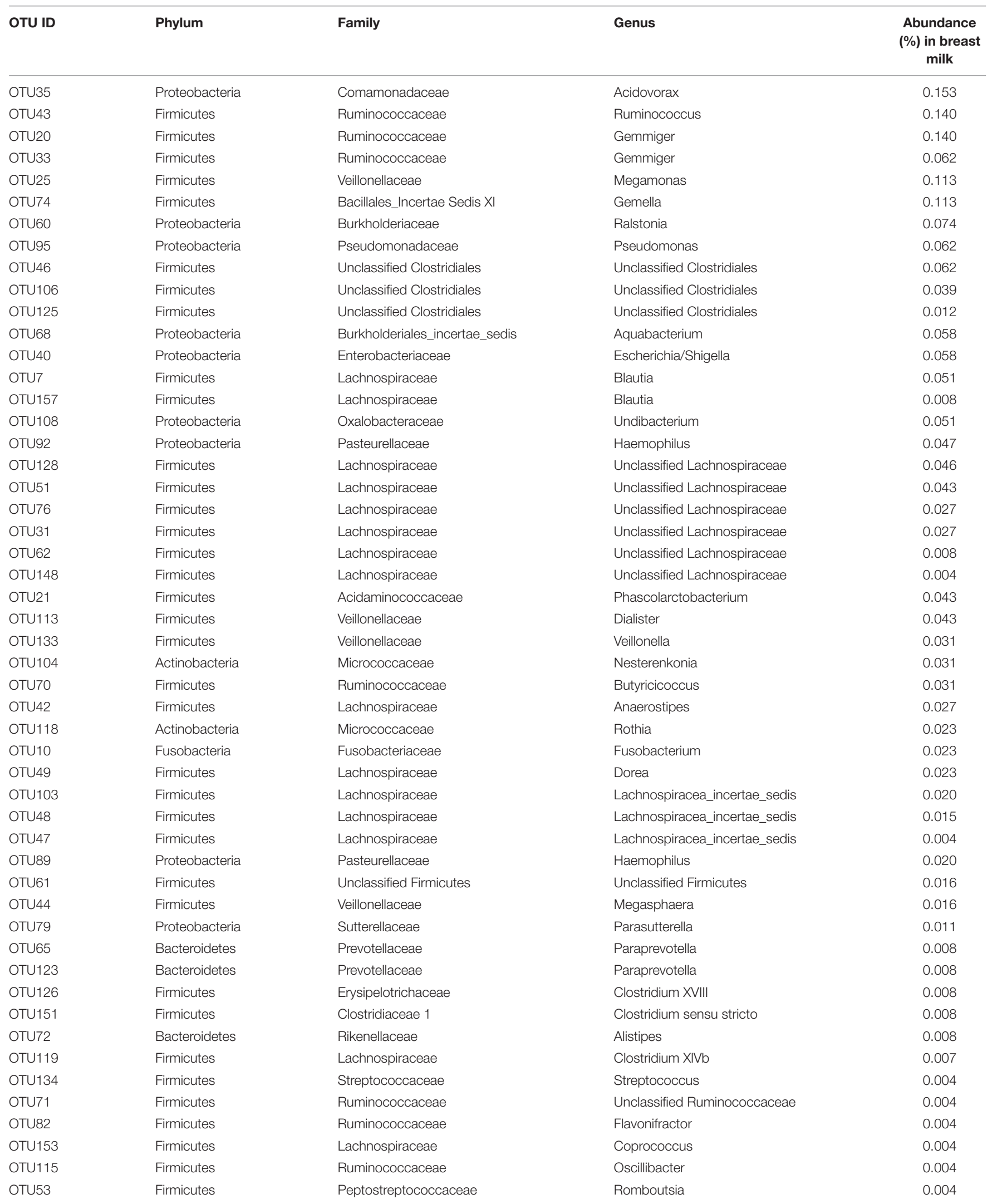


at abundance $0.01-0.1 \%$, but not in any recipient mice (Table 2).

Bacteria from Bifidobacterium, represented by OTU55 and OTU19, were not detected in the breast milk inoculum, but were detected at abundance $0.003-0.01 \%$ in some recipient mice at week 8 (Table 3). In one mouse (D7), the two Bifidobacterium OTUs were repeatedly detected from weeks 4 to 8 (Supplementary Figure S3 and Table S2).

\section{Isolation of Bacteria from the Breast Milk Inoculum and the Feces of One Recipient Mouse}

Bacteria were isolated from the breast milk inoculum and the feces of No. 4 recipient mouse at week 8 . The No.4 mouse was selected because its DGGE profile at week 8 contained all the six dominant bands detected in other recipient mice (Figure 1). WCH and M17 media were used because previous studies showed the majority of bacteria isolated from human breast milk grew on WCH medium (Jost et al., 2013), and streptococci, lactococci, and enterococci grew better on M17 than on MRS agar plates (Heikkila and Saris, 2003).

The viable bacterial counts in the breast milk inoculum were $\log 5.18 \pm 0.15 \mathrm{cfu} / \mathrm{ml}$ (range $\log 4.97-5.3 \mathrm{cfu} / \mathrm{ml}$ ) and $\log$ $3.97 \pm 0.09 \mathrm{cfu} / \mathrm{ml}$ (range log 3.9-4.1 cfu/ml) as detected by WCH and M17, respectively. The bacterial counts of mouse feces were $9.28 \pm 0.23 \mathrm{cfu} / \mathrm{g}$ (range $\log 8.87-9.54 \mathrm{cfu} / \mathrm{g}$ ) and $\log 9.49 \pm 0.28$ cfu/g (range log 9.11-9.78 cfu/g) as detected by WCH and M17, respectively.
One hundred and eighty-six isolates (148 on $\mathrm{WCH}$, and 40 on M17) and 282 isolates (119 on WCH, and 163 on M17) were isolated from the breast milk inoculum and the mouse feces, respectively. With ERIC PCR, the 186 isolates of the breast milk were genotyped into 12 different ERIC types (BM-E1 to BM-E12), and the 282 isolates of the mouse feces were classified into 5 ERIC types (MF-E13 to MF-E17) (Supplementary Figure S4). The breast milk and mouse feces isolates shared no common ERIC type (Supplementary Figure S4).

The taxonomy of the isolates was determined at the specieslevel by constructing a phylogenetic tree with the full-length $16 \mathrm{~S}$ rRNA gene sequences of the representative strains of individual ERIC types (Figure 3), and the abundance of each bacterial species in the original sample was calculated as its percentage accounting for the total number of all isolates of the sample. Among the breast milk isolates, $90.9 \%$ were Staphylococcus species and only $9.1 \%$ were Streptococcus. Among the mouse fecal isolates, however, the percentage of Staphylococcus spp. was greatly reduced to $15.2 \%$, and Streptococcus isolates accounted for as much as $84.7 \%$ (Table 4). This is consistent with the $16 \mathrm{~S}$ rRNA gene Illumina sequencing result.

In accordance with the DGGE result, bacterial isolates belonging to Str. parasanguinis were not obtained from the milk, but were the most abundant isolates in the mouse feces (Table 4). The sequence of 16S rRNA gene V3-V4 region of the representative Str. parasanguinis isolate was compared to the representative sequences of OTUs belonging to Streptococcus from the Illumina sequencing results of $16 \mathrm{~S}$ rRNA gene of the milk and mouse feces. It showed $99 \%$ similarity to the

TABLE 3 | OTUs detected only in the feces of recipient mice at week 8 but not in the breast milk inoculum.

\begin{tabular}{|c|c|c|c|c|c|c|}
\hline OTU ID & Phylum & Family & Genus & $\begin{array}{c}\text { Abundance } \\
(\%) \text { in breast } \\
\text { milk }\end{array}$ & $\begin{array}{c}\text { Number of mice } \\
\text { harboring the } \\
\text { OTU§ }\end{array}$ & $\begin{array}{c}\text { Range of abundance } \\
\text { (\%) of the OTU in the } \\
\text { mice harboring the } \\
\text { OTU }\end{array}$ \\
\hline OTU94 & Firmicutes & Streptococcaceae & Streptococcus & 0 & 5 & $0.003-0.006$ \\
\hline OTU55 & Actinobacteria & Bifidobacteriaceae & Bifidobacterium & 0 & 3 & $0.003-0.006$ \\
\hline OTU19 & Actinobacteria & Bifidobacteriaceae & Bifidobacterium & 0 & 2 & 0.003 \\
\hline OTU130 & Proteobacteria & Rhodocyclaceae & Dechloromonas & 0 & 2 & $0.003-0.006$ \\
\hline OTU83 & Actinobacteria & Bogoriellaceae & Bogoriella & 0 & 2 & 0.003 \\
\hline OTU57 & Verrucomicrobia & Verrucomicrobiaceae & Akkermansia & 0 & 1 & 0.006 \\
\hline OTU137 & Proteobacteria & Alcanivoracaceae & Alcanivorax & 0 & 1 & 0.003 \\
\hline OTU52 & Bacteroidetes & Rikenellaceae & Alistipes & 0 & 1 & 0.003 \\
\hline OTU38 & Bacteroidetes & Bacteroidaceae & Bacteroides & 0 & 1 & 0.003 \\
\hline OTU75 & Bacteroidetes & Bacteroidaceae & Bacteroides & 0 & 1 & 0.003 \\
\hline OTU121 & Actinobacteria & Coriobacteriaceae & Collinsella & 0 & 1 & 0.003 \\
\hline OTU45 & Firmicutes & Lachnospiraceae & Coprococcus & 0 & 1 & 0.003 \\
\hline OTU86 & Firmicutes & Erysipelotrichaceae & Holdemanella & 0 & 1 & 0.003 \\
\hline OTU112 & Bacteroidetes & Porphyromonadaceae & Odoribacter & 0 & 1 & 0.003 \\
\hline OTU150 & Bacteroidetes & Porphyromonadaceae & Parabacteroides & 0 & 1 & 0.003 \\
\hline OTU34 & Bacteroidetes & Prevotellaceae & Prevotella & 0 & 1 & 0.003 \\
\hline OTU154 & Proteobacteria & Rhodocyclaceae & Thauera & 0 & 1 & 0.003 \\
\hline OTU59 & Actinobacteria & Microbacteriaceae & Unclassified Microbacteriaceae & 0 & 1 & 0.003 \\
\hline OTU129 & Firmicutes & Ruminococcaceae & Unclassified Ruminococcaceae & 0 & 1 & 0.003 \\
\hline
\end{tabular}

§Ten mice in total. 


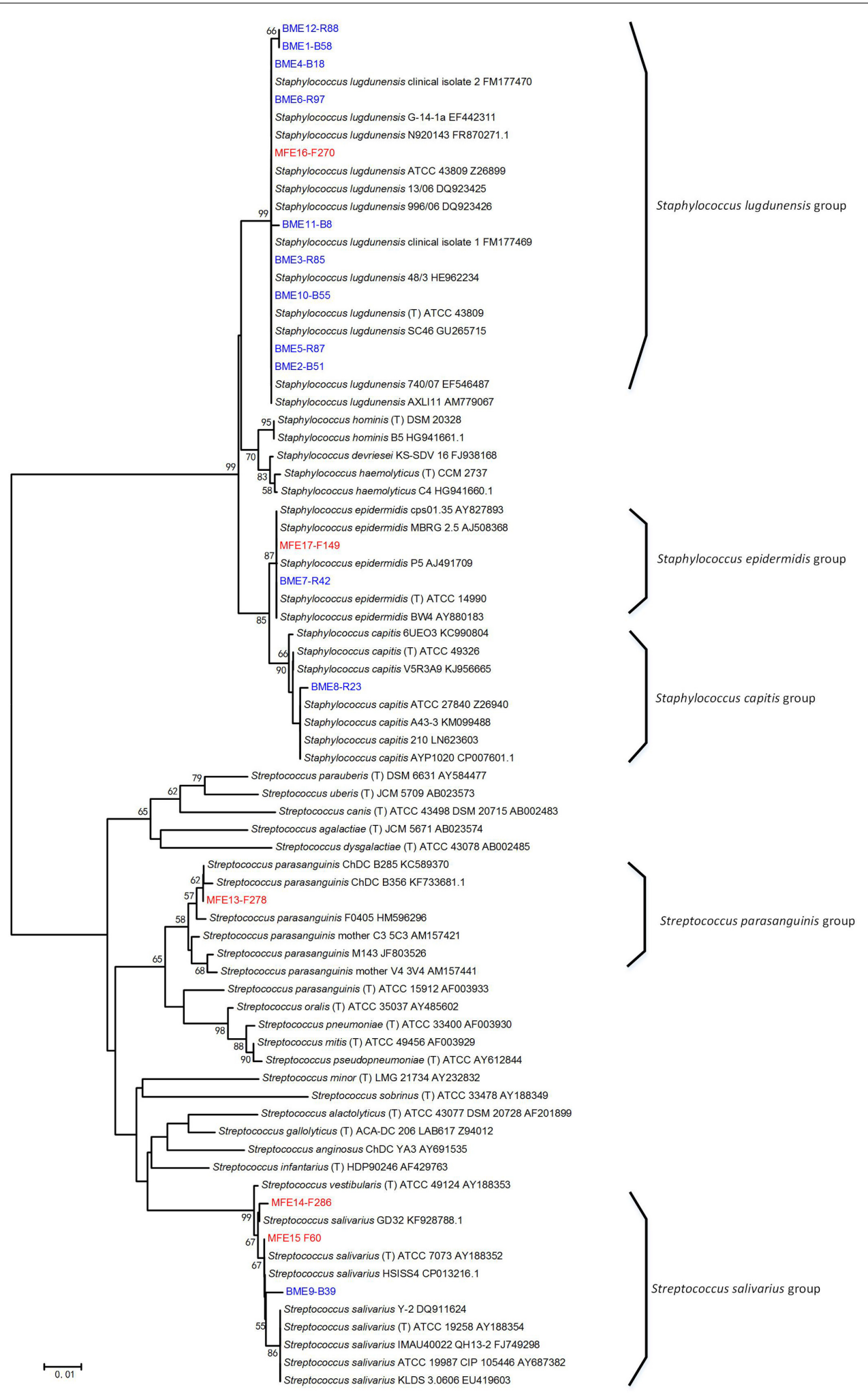

FIGURE 3 | Phylogenetic tree of the representative bacterial isolates of 17 ERIC types and other known bacteria. The tree was constructed based on the region from base 27 to base 1492 of the 16S rRNA genes. The ERIC types isolated from breast milk (BME 1-12) and from the feces of No. 4 recipient mouse (MFE 13-17) are indicated by blue and red font, respectively, and the ID of the representative strain of each ERIC type was written after. Bacterial strains retrieved from the GenBank database are indicated by italics, and their accession numbers are given. Bootstrap values greater than $50 \%$ are indicated at the nodes. 
TABLE 4 | The taxonomy and abundance of the bacteria isolated from the breast milk inoculum and the feces of No. 4 mouse at week 8.

\begin{tabular}{lccc}
\hline Genus & Species $^{\S}$ & $\begin{array}{c}\text { Abundance in } \\
\text { breast milk } \\
(\mathbf{( \% )}\end{array}$ & $\begin{array}{c}\text { Abundance in } \\
\text { mouse feces } \\
(\mathbf{( \% )})^{\boldsymbol{9}}\end{array}$ \\
\hline Staphylococcus & S. lugdunensis & 90.9 & 15.2 \\
& S. epidermidis & 99 & 13.8 \\
Streptococcus & S. capitis & 2.2 & 1.4 \\
& Str. salivarius & 9.1 & $/$ \\
& Str. parasanguinis & 9.1 & 84.7 \\
& & $/$ & 65.6
\end{tabular}

$\S$ The taxonomy of the bacteria is determined based on the phylogenetic tree constructed with the full-length 16S rRNA gene of the isolated strains and those deposited in GenBank (Figure 3). "The abundance of individual bacterial species is the percentage of the species accounting for the total isolated strains from the sample these bacteria were isolated. One hundred and eighty-six and 282 strains were isolated from the breast milk inoculum and mouse feces, respectively.

representative sequence of OTU1, but only $97 \%$ similarity to OTU4 and OTU134. These results suggest Str. parasanguinis was classified within OTU1 from the Illumina sequencing results of $16 \mathrm{~S}$ rRNA gene of the milk and mouse feces.

\section{DISCUSSION}

Our results suggest that typically gut-associated bacteria detectable in human breast milk are alive and could stably colonize the intestine of germ-free mice. The breast milk bacteria that became most abundant $(>1 \%)$ in all 10 recipient mice were Streptococcus (80.3 $\pm 2.3 \%)$, Corynebacterium (10 $\pm 2.6 \%)$, Staphylococcus (7.6 $\pm 1.6 \%)$, and Propionibacterium ( $2.1 \pm 0.5 \%)$. These bacteria are among the first colonizers in the colon of human infants within the first weeks of life (Palmer et al., 2007; Backhed et al., 2015), and they have been shown to dominate the initial gut microbiota of C-section-delivered human babies (Dominguez-Bello et al., 2010), despite that their predominance in the gut persists only in the first weeks of life (Palmer et al., 2007; Backhed et al., 2015; Charbonneau et al., 2016). Of note, Streptococcus spp. are also prevalent species in the gut of Chinese children and adults, and the abundance can reach as high as 5-9\% in some Chinese individuals according to Illumina sequencing of fecal 16S rRNA gene fragments (Zhang C. et al., 2015; Zhang J. et al., 2015). Bacteria within Faecalibacterium, Prevotella, Roseburia, Unclassified Lachnospiraceae, Ruminococcus, and Bacteroides are dominant gut bacteria in children and adults (Eckburg et al., 2005; Arumugam et al., 2011), and they were present in the breast milk inoculum and were repeatedly detected at multiple time points in the feces of some recipient mice. Bifidobacterium spp. have been identified as important bacteria that are vertically transferred from maternal breast milk to infant gut in humans (Martin et al., 2012; Jost et al., 2014). In the present study, the breast milk inoculum was the only source of commensal bacteria for the recipient mice, and bifidobacteria were detected in the feces of recipient mice but not in the breast milk inoculum with Illumina sequencing of $16 \mathrm{~S}$ rRNA gene. This suggests that the gut of our breast milk microbiotaassociated mice enriched bifidobacteria despite their abundance in the milk inoculum below the detection limit of Illumina sequencing of $16 \mathrm{~S}$ rRNA gene. Among the bacteria discussed above, except Staphylococcus and Bifidobacterium (Martin et al., 2012; Jost et al., 2014), were those previously identified to be present in human breast milk, but direct evidence for their colonization of the infant gut has been lacking. Therefore, our results indicate the breast milk microbiota-associated mouse model can be used to identify additional breast milk bacteria that have the potential to colonize infant gut.

In human neonates, Propionibacterium spp. were found to be one of the pioneer colonizers in the gut (Dominguez-Bello et al., 2010; Backhed et al., 2015), but could not be detected in their mothers' gut (Backhed et al., 2015). In the present study, the human breast milk Propionibacterium spp. were able to colonize the gut of germ-free mice, suggesting that breast milk may be one of sources of infant gut Propionibacterium.

Streptococcus spp. and Staphylococcus spp. are facultative anaerobes, and Corynebacterium and Propionibacterium genera include both aerobic and facultatively anaerobic species (Pascual et al., 1995; Collins and Cummins, 2005; Stackebrandt et al., 2006), and they were the only four genera at $>1 \%$ abundance in the gut of our recipient mice. The very low abundance of Corynebacterium and Propionibacterium in the milk inoculum, which was as low as 0.004 and $0.02 \%$, respectively, did not hamper them blooming in the gut of recipient mice. In contrast, the obligatory anaerobes, Faecalibacterium, Prevotella, Roseburia, Unclassified Lachnospiraceae, Ruminococcus, and Bacteroides stayed at very low abundance in recipient mice (0.003-0.01\%). The dominance of aerobic or facultative anaerobic bacteria over obligatory anaerobes in the colon of our recipient mice resemble the observation of gut microbiota composition of human neonates in the first week of life (Palmer et al., 2007), and this is probably because the intestine of both germ-free mice (Celesk et al., 1976) and human newborns younger than 1 -week-old is still in an aerobic condition. However, while the aerobic or facultative anaerobic bacteria are replaced by obligatory anaerobic bacteria within first weeks of life in the gut microbiota of human infants (Palmer et al., 2007), the fecal microbiota of our recipient mice stabilized with the dominance of aerobic or facultative anaerobic bacteria for 4-6 weeks in different mice. This indicates that factors that promote the growth of obligatory anaerobes in the gut are lacking for the breast milk microbiota-associated mice.

Diet exerts a determinant effect in shaping the composition of gut microbiota. In human infants, breast feeding results in bifidobacteria-dominating gut microbiota (Charbonneau et al., 2016), whereas formula feeding makes the infant gut microbiota an "adult-like microbiota" in which Bacteroides, members of the Clostridium coccoides group, and Lactobacillus are all predominantly represented (Fallani et al., 2010). In human adults, prebiotic inulin ingestion significantly increases the abundance of Faecalibacterium prausnitzii (Ramirez-Farias et al., 2009). In future studies, it would be worthwhile to feed the breast milk microbiota-associated mice with formula and prebiotics, which may enrich obligatory anaerobes in the gut of these mice. 
This breast milk microbiota-associated mouse model might provide an alternative way to isolate the gut-associated bacteria from the breast milk. In previous studies using varying culture media, about $60 \%$ of the bacterial isolates of the breast milk were Staphylococcus spp. (Heikkila and Saris, 2003; Jimenez et al., 2008; Jost et al., 2013, 2014), which are prevalent and dominant on human skin (Grice et al., 2009). In agreement with these previous findings that bacterial isolates of the breast milk were predominantly Staphylococcus, the bacterial cultivation in the present study showed Staphylococcus accounted for 90.9\% of the isolates of the breast milk. In contrast, in the feces of our breast milk microbiota-associate mice, the percentage of Staphylococcus isolates decreased to only $15.2 \%$, and isolates of Streptococcus bacteria, which are prevalent in the gut microbiota of Chinese people (Zhang C. et al., 2015; Zhang J. et al., 2015), accounted for $84.7 \%$. Furthermore, our results showed that the facultative anaerobic gut-associated bacteria from the breast milk inoculum stably colonized the gut of recipient mice, and that obligatory anaerobes were repeatedly detected at multiple time points in some recipient mice. These results suggest breast milk microbiota-associated mice can serve as sustainable carriers for these bacteria and can continuously provide feces for isolation of these bacteria.

In conclusion, our results showed the typically gut-associated bacteria in human breast milk could colonize the gut of germfree

\section{REFERENCES}

Arumugam, M., Raes, J., Pelletier, E., Le Paslier, D., Yamada, T., Mende, D. R., et al. (2011). Enterotypes of the human gut microbiome. Nature 473, 174-180. doi: 10.1038/nature09944

Backhed, F., Roswall, J., Peng, Y., Feng, Q., Jia, H., Kovatcheva-Datchary, P., et al. (2015). Dynamics and stabilization of the human gut microbiome during the first year of life. Cell Host Microbe 17, 690-703. doi: 10.1016/j.chom.2015.04.004

Cabrera-Rubio, R., Collado, M. C., Laitinen, K., Salminen, S., Isolauri, E., and Mira, A. (2012). The human milk microbiome changes over lactation and is shaped by maternal weight and mode of delivery. Am. J. Clin. Nutr. 96, 544-551. doi: 10.3945/ajen.112.037382

Celesk, R. A., Asano, T., and Wagner, M. (1976). The size, pH, and redox potential of the cecum in mice associated with various microbial floras. Proc. Soc. Exp. Biol. Med. 151, 260-263. doi: 10.3181/00379727-151-39187

Charbonneau, M. R., Blanton, L. V., DiGiulio, D. B., Relman, D. A., Lebrilla, C. B., Mills, D. A., et al. (2016). A microbial perspective of human developmental biology. Nature 535, 48-55. doi: 10.1038/nature 18845

Cole, J. R., Wang, Q., Fish, J. A., Chai, B., McGarrell, D. M., Sun, Y., et al. (2014). Ribosomal database project: data and tools for high throughput rRNA analysis. Nucleic Acids Res. 42, D633-D642. doi: 10.1093/nar/gkt1244

Collado, M. C., Delgado, S., Maldonado, A., and Rodriguez, J. M. (2009). Assessment of the bacterial diversity of breast milk of healthy women by quantitative real-time PCR. Lett. Appl. Microbiol. 48, 523-528. doi: 10.1111/j. 1472-765X.2009.02567.x

Collins, M. D., and Cummins, C. S. (2005). "Genus Corynebacterium Lehmann and Neumann 1896," in Bergey's Manual of Systematic Bacteriology, eds P. H. A. Sneath, N. S. Mair, M. E. Sharpe, and J. G. Holt (Singapore: Springer Verlag).

de Bruijn, F. J. (1992). Use of repetitive (repetitive extragenic palindromic and enterobacterial repetitive intergeneric consensus) sequences and the polymerase chain reaction to fingerprint the genomes of Rhizobium meliloti isolates and other soil bacteria. Appl. Environ. Microbiol. 58, 2180-2187.

Dominguez-Bello, M. G., Costello, E. K., Contreras, M., Magris, M., Hidalgo, G., Fierer, N., et al. (2010). Delivery mode shapes the acquisition and structure of the initial microbiota across multiple body habitats in newborns. Proc. Natl. Acad. Sci. U.S.A. 107, 11971-11975. doi: 10.1073/pnas.1002601107 mice, and this breast milk microbiota-associated mouse model may be used to identify additional breast milk bacteria that can colonize the gut and are thus potentially involved in human mother-infant bacterial transfer via breast feeding.

\section{AUTHOR CONTRIBUTIONS}

LZ and JS designed the study; XW, HL, XX, JC, and CF collected the breast milk sample; XW performed the experiments; XW, ZF, and JS analyzed the data; XW, LZ, and JS wrote and revised the manuscript.

\section{FUNDING}

This work was supported by grants from the National Natural Science Foundation of China (81570809).

\section{SUPPLEMENTARY MATERIAL}

The Supplementary Material for this article can be found online at: http://journal.frontiersin.org/article/10.3389/fmicb. 2017.01242/full\#supplementary-material

Eckburg, P. B., Bik, E. M., Bernstein, C. N., Purdom, E., Dethlefsen, L., Sargent, M., et al. (2005). Diversity of the human intestinal microbial flora. Science 308, 1635-1638. doi: 10.1126/science.1110591

Edgar, R. C. (2010). Search and clustering orders of magnitude faster than BLAST. Bioinformatics 26, 2460-2461. doi: 10.1093/bioinformatics/btq461

Edgar, R. C. (2013). UPARSE: highly accurate OTU sequences from microbial amplicon reads. Nat. Methods 10, 996-998. doi: 10.1038/nmeth.2604

Edgar, R. C., Haas, B. J., Clemente, J. C., Quince, C., and Knight, R. (2011). UCHIME improves sensitivity and speed of chimera detection. Bioinformatics 27, 2194-2200. doi: 10.1093/bioinformatics/btr381

Fallani, M., Young, D., Scott, J., Norin, E., Amarri, S., Adam, R., et al. (2010). Intestinal microbiota of 6-week-old infants across Europe: geographic influence beyond delivery mode, breast-feeding, and antibiotics. J. Pediatr. Gastroenterol. Nutr. 51, 77-84. doi: 10.1097/MPG.0b013e3181d1b11e

Godon, J. J., Zumstein, E., Dabert, P., Habouzit, F., and Moletta, R. (1997). Molecular microbial diversity of an anaerobic digestor as determined by small-subunit rDNA sequence analysis. Appl. Environ. Microbiol. 63, 2802-2813.

Grice, E. A., Kong, H. H., Conlan, S., Deming, C. B., Davis, J., Young, A. C., et al. (2009). Topographical and temporal diversity of the human skin microbiome. Science 324, 1190-1192. doi: 10.1126/science.1171700

Gueimonde, M., Laitinen, K., Salminen, S., and Isolauri, E. (2007). Breast milk: a source of bifidobacteria for infant gut development and maturation? Neonatology 92, 64-66. doi: 10.1159/000100088

Heikkila, M. P., and Saris, P. E. J. (2003). Inhibition of Staphylococcus aureus by the commensal bacteria of human milk. J. Appl. Microbiol. 95, 471-478. doi: 10.1046/j.1365-2672.2003.02002.x

Hunt, K. M., Foster, J. A., Forney, L. J., Schutte, U. M., Beck, D. L., Abdo, Z., et al. (2011). Characterization of the diversity and temporal stability of bacterial communities in human milk. PLOS ONE 6:e21313. doi: 10.1371/journal.pone. 0021313

Jimenez, E., Delgado, S., Fernandez, L., Garcia, N., Albujar, M., Gomez, A., et al. (2008). Assessment of the bacterial diversity of human colostrum and screening of staphylococcal and enterococcal populations for potential virulence factors. Res. Microbiol. 159, 595-601. doi: 10.1016/j.resmic.2008. 09.001 
Jost, T., Lacroix, C., Braegger, C., and Chassard, C. (2013). Assessment of bacterial diversity in breast milk using culture-dependent and culture-independent approaches. Br. J. Nutr. 110, 1253-1262. doi: 10.1017/S0007114513000597

Jost, T., Lacroix, C., Braegger, C. P., Rochat, F., and Chassard, C. (2014). Vertical mother-neonate transfer of maternal gut bacteria via breastfeeding. Environ. Microbiol. 16, 2891-2904. doi: 10.1111/1462-2920.12238

Kibe, R., Sakamoto, M., Yokota, H., Ishikawa, H., Aiba, Y., Koga, Y., et al. (2005). Movement and fixation of intestinal microbiota after administration of human feces to germfree mice. Appl. Environ. Microbiol. 71, 3171-3178. doi: 10.1128/ aem.71.6.3171-3178.2005

Martin, F. P., Dumas, M. E., Wang, Y., Legido-Quigley, C., Yap, I. K., Tang, H., et al. (2007). A top-down systems biology view of microbiome-mammalian metabolic interactions in a mouse model. Mol. Syst. Biol. 3:112. doi: 10.1038/ msb4100153

Martin, R., Heilig, H. G., Zoetendal, E. G., Jimenez, E., Fernandez, L., Smidt, H., et al. (2007). Cultivation-independent assessment of the bacterial diversity of breast milk among healthy women. Res. Microbiol. 158, 31-37. doi: 10.1016/j. resmic.2006.11.004

Martin, R., Jimenez, E., Olivares, M., Marin, M. L., Fernandez, L., Xaus, J., et al. (2006). Lactobacillus salivarius CECT 5713, a potential probiotic strain isolated from infant feces and breast milk of a mother-child pair. Int. J. Food Microbiol. 112, 35-43. doi: 10.1016/j.ijfoodmicro.2006.06.011

Martin, V., Maldonado-Barragan, A., Moles, L., Rodriguez-Banos, M., Campo, R. D., Fernandez, L., et al. (2012). Sharing of bacterial strains between breast milk and infant feces. J. Hum. Lact. 28, 36-44. doi: 10.1177/089033441142 4729

Muyzer, G., de Waal, E. C., and Uitterlinden, A. G. (1993). Profiling of complex microbial populations by denaturing gradient gel electrophoresis analysis of polymerase chain reaction-amplified genes coding for $16 \mathrm{~S}$ rRNA. Appl. Environ. Microbiol. 59, 695-700.

Palmer, C., Bik, E. M., DiGiulio, D. B., Relman, D. A., and Brown, P. O. (2007). Development of the human infant intestinal microbiota. PLoS Biol. 5:e177. doi: 10.1371/journal.pbio.0050177

Pascual, C., Lawson, P. A., Farrow, J. A., Gimenez, M. N., and Collins, M. D. (1995). Phylogenetic analysis of the genus Corynebacterium based on 16S rRNA gene sequences. Int. J. Syst. Bacteriol. 45, 724-728. doi: 10.1099/00207713-454-724

Perez, P. F., Dore, J., Leclerc, M., Levenez, F., Benyacoub, J., Serrant, P., et al. (2007). Bacterial imprinting of the neonatal immune system: lessons from maternal cells? Pediatrics 119:e724-32. doi: 10.1542/peds.2006-1649
Ramirez-Farias, C., Slezak, K., Fuller, Z., Duncan, A., Holtrop, G., and Louis, P. (2009). Effect of inulin on the human gut microbiota: stimulation of Bifidobacterium adolescentis and Faecalibacterium prausnitzii. Br. J. Nutr. 101, 541-550. doi: 10.1017/s0007114508019880

Ridaura, V. K., Faith, J. J., Rey, F. E., Cheng, J., Duncan, A. E., Kau, A. L., et al. (2013). Gut microbiota from twins discordant for obesity modulate metabolism in mice. Science 341:1241214. doi: 10.1126/science. 1241214

Stackebrandt, E., Cummins, C. S., and Johnson, J. L. (2006). "The genus Propionibacterium," in The Prokaryotes, eds M. Dworkin, S. Falkow, E. Rosenberg, K. H. Schleifer, and E. Stackebrandt (Singapore: Springer Verlag).

Turnbaugh, P. J., Ridaura, V. K., Faith, J. J., Rey, F. E., Knight, R., and Gordon, J. I. (2009). The effect of diet on the human gut microbiome: a metagenomic analysis in humanized gnotobiotic mice. Sci. Transl. Med. 1, 6ra14. doi: 10.1126/ scitranslmed.3000322

Wei, G., Pan, L., Du, H., Chen, J., and Zhao, L. (2004). ERIC-PCR fingerprintingbased community DNA hybridization to pinpoint genome-specific fragments as molecular markers to identify and track populations common to healthy human guts. J. Microbiol. Methods 59, 91-108. doi: 10.1016/j.mimet.2004. 06.007

Zhang, C., Yin, A., Li, H., Wang, R., Wu, G., Shen, J., et al. (2015). Dietary modulation of gut microbiota contributes to alleviation of both genetic and simple obesity in children. EBioMedicine 2, 968-984. doi: 10.1016/j.ebiom.2015. 07.007

Zhang, J., Guo, Z., Xue, Z., Sun, Z., Zhang, M., Wang, L., et al. (2015). A phylofunctional core of gut microbiota in healthy young Chinese cohorts across lifestyles, geography and ethnicities. ISME J. 9, 1979-1990. doi: 10.1038/ismej. 2015.11

Conflict of Interest Statement: The authors declare that the research was conducted in the absence of any commercial or financial relationships that could be construed as a potential conflict of interest.

Copyright (c) 2017 Wang, Lu, Feng, Cao, Fang, Xu, Zhao and Shen. This is an open-access article distributed under the terms of the Creative Commons Attribution License (CC BY). The use, distribution or reproduction in other forums is permitted, provided the original author(s) or licensor are credited and that the original publication in this journal is cited, in accordance with accepted academic practice. No use, distribution or reproduction is permitted which does not comply with these terms. 